\title{
Private equity and HRM in the British business system
}

Ian Clark, International Management and Organization Research Group, The University of Birmingham, UK Human Resource Management Journal, Vol 17, no 3, 2007, pages 218-226

Who owns the firm? Do changes in owner matter? Will change affect the operational and strategic role of the HR function? For some, the answer will be no precisely because mergers and acquisitions, takeovers, buyouts and privatisations are central activities for a British-based business where short-term value for shareholders and financial engineering are key management objectives that structure and inform the work of HR professionals. For other readers, the answer may well be yes; ownership and owner strategies do matter, particularly if a firm is acquired by a relatively new actor in the market for corporate control - the private equity firm.

Contact: Ian Clark, International Management and Organization Research Group, The University of Birmingham, Edgbaston, Birmingham B15 2TT, UK. Email: i.a.clark@bham.ac.uk

\section{INTRODUCTION}

The private equity sector within Britain's capital market provides a specific business model designed to support start-up and established businesses. It involves innovative financial, commercial and operational strategies that aim to enhance company efficiency. A recently published Financial Services Authority (FSA) discussion paper on private equity defines the sector as one that 'matches medium to long-term capital with companies that are not quoted on public equity markets and which need finance to fund growth, development and business improvement' (FSA, 2006: 12). However, the discussion paper does endorse the view of practitioner bodies to note that the activity of the sector and its fund managers extends beyond private firms. On some occasions, this activity may witness 'take private' deals whereby via a combination of equity and bank debt private equity firms (PEFs) acting for themselves, a consortium of banks or individuals buy out all the publicly quoted shares in a company taking the company private. So in summary, PEFs establish and operate collective investment schemes and advise on, assess and manage investment deals for clients (FSA, 2006: 79). PEFs are predominantly funded by institutional investors such as pension funds, commercial and retail banks, insurance companies, government agencies and local authorities. PEFs focus on the legal duty to maximise value for shareholders and may break up a company, selling up to 50 per cent of its assets to reduce any debt levels incurred in a purchase.

Despite a vast literature on HRM and corporate restructuring, relatively little is known about private equity. As the FSA paper points out, as privately owned entities, many PEFs are free from regulatory and transparency mechanisms to which publicly quoted firms are subject. As the FSA discussion paper further demonstrates, 
PEFs are unregulated actors in a business system with comparatively few institutional and statutory constraints that impose on HR practices. Moreover, while the FSA's discussion paper is otherwise comprehensive in its coverage and treatment of a potential regulatory framework and its impact on market practices and associated risks, there is virtually no mention of issues associated with the employment relationship or the management of human resources. This is the case despite the fact that in 2006, private equity directly controlled the management of 2.8 million employees or 20 per cent of the UK's private sector (British Venture Capital Association (BVCA), 2006a) and indirectly contributed to the management of many other employees whose investments are placed in their hands by institutional actors such as pension funds and insurance companies.

This research note provides a description of private equity under four headings. The next section provides some background detail on the research issues under evaluation and then goes on to provide a general summary of the sector outlining its significance for the HR community of scholars and practitioners. The third section identifies related research questions, the objectives therein and the significance of these points to wider debates about the emergence of shareholder capitalism. A particular focus for wider debate centres on the emergence of shareholder capitalism as a development within established patterns of industrial capitalism, or a change in the underlying rationale that drives national varieties of industrial capitalism. Finally, the article raises further pertinent questions for policy and academic research in particular, the impact of the sector on academic representations of business contexts that surround HRM.

\section{BACKGROUND TO THE RESEARCH QUESTION}

A recent research project that reported on HR strategies in US multinational firms across Europe examined the interplay of relations between corporate headquarters in the USA and subsidiary operations in Europe (Almond and Ferner, 2006). The study confirmed some issues of debate in the literature, for example that US MNCs tend to diffuse highly centralised, formalised and standardised approaches to HR, but in addition identified new areas for research, for example the significance of sector effects and subsidiary autonomy from HQ control and dictate (Clark et al., 2002; Colling and Clark, 2002, 2006). Still further, the study revealed new and emergent pressures on line and HR managers associated with the phenomenon of shareholder value, venture capital and private equity investors (Clark and Almond, 2004).

A more detailed examination of private equity established three under-reported and under-researched findings. First, while in the UK, the diffusion of pressures on firms to manage in the interests of shareholder value was first associated with subsidiaries of US MNCs, short-termism and financial engineering is a welldeveloped and long-established index of business performance in the British business system. Second, until recently, the private equity sector was largely invisible and not reported on by the media or HR/IR academics. Third, while first developed in the USA, there is a well-developed British-based, British-owned component to the sector. 
PRIVATE EQUITY FIRMS IN THE MARKET FOR CORPORATE CONTROL: THE DEAL, RESTRUCTURING AND EXIT

Plc firms raise most of their capital in the form of equity that is traded on a public stock market. In contrast to this, PEFs raise investment funds from institutional investors to buy up to 20 start-up or established firms per fund. Purchases are usually highly leveraged, with around 70 per cent of a deal funded by debt. Supporting start-ups or 'taking private' publicly quoted companies enables PEFs to restructure the financial, commercial and operational priorities of a firm to secure a return for their own investors.

\section{Private equity deals}

Whether funding new or established businesses, the stock-in-trade of PEFs is a proven capability to transform, develop and grow businesses significantly by increasing their operational potential; hence, market and managerial expertise is a core competence of private equity practitioners. The second half of 2006 saw $£ 10$ billion finance over 40 private equity deals, including six 'take private' deals and nine $£ 250$ billion + deals (KPMG, 2006). While these are UK-based deals, private equity funding is sourced internationally with the top six deals involving an overseas provider. More significantly, in 2005, only 21 per cent of the funds raised by the UK sector came from the UK, with the USA providing 45 per cent and with continental providers supplying a further 22 per cent (FSA, 2006: 13). In 2006, deal conditions remained buoyant with a rising equity market and cash rich institutions bidding up potential prices for private equity deals. In addition, a tendency for some PEFs to replace or not back existing management and to introduce more aggressive HR strategies, the so-called 'Gate Gourmet effect', has made some managements and family owners reluctant to sell out but wait for better offers, for example HMV and Sainsbury's.

\section{Restructuring}

A private equity bid is a function of perceived growth potential, not just current fundamentals such as cash flow. Ultimately, restructuring involves buying, transforming and increasing the value of a company. The FSA (2006: 45) terms this 'professionalising' a company, its management structure and internal reporting lines and mechanisms and installing 'superior' financial engineering systems to achieve greater financial control. Reminiscent of the strategic choice interface with HRM (see Boxall and Purcell, 2003: 27-47), restructuring operates at three orders of significance.

Financial restructuring Profits for the fund and the acquired firm are only achievable if costs can be reduced by tightening contract margins and slimming overheads and revenues raised by selling non-core business, refocusing 'the offer' in existing and new markets. First-order financial decisions centre on how to fund debt levels and share-buy-backs and how to return cash to lenders. Raising profit levels by financial engineering is a key measure of success, as is outperformance in the market by improving market share. 
Commercial restructuring Commercial restructuring - that is, the relationship of internal parts of a business to one another - flows directly from financial restructuring. Divestment and revenue generation refocus internal priorities in respect of costs, asset base, asset management and customer service relations. Second-order priorities define the commercial potential that results from financial restructuring as a first-order priority. In a language more familiar to the HR community, this means redefining the core group of workers with the resultant downsizing that follows.

Operational restructuring Private equity managers are not only financial engineers; they also claim to be better managers who benefit society more widely by boosting employment and profitability in British business (Jackson, 2006). While private equity-backed firms may create unemployment because of financial and commercial restructuring, they also appear to create jobs at a much faster rate than the FTSE top 100 and 250 companies, averaging a 9 per cent growth in employment since 2001 compared to 1 and 2 per cent per annum, respectively for FTSE companies. However, these claims are subject to emerging critical analysis; see, for example, Folkman et al. (2006) and Froud and Williams (2007). More controversially, self-reporting claims that the majority of this growth is organic rather than that which results from merger and acquisition (BVCA, 2006b). Private equity practitioners and peak associations such as the BVCA claim that this success rests on a positive HR motivation that contributes to the release of the full potential of employees and management, in the main by re-engineering remuneration packages for senior management and their teams. In practitioner and peak association publications and in the financial economics literature, the details of these policies and strategies remain opaque other than agency-based references to the alignment of remuneration packages with owner and investor interests.

\section{Exit}

To satisfy the demands of their investors and to secure their own percentages (up to 20 per cent of profits and a transaction charge of 1.5 per cent on profit - both per annum) plus any speculative return on shares that are privately owned by fund partners, it is necessary to sell-on the acquired firm. The usual exit routes are an initial public offering for a previously acquired start-up, returning a once public company to the stock market or slavishly selling on bits or the whole of the firm in the secondary private equity market.

Private equity is often likened to asset stripping; and although there are some similarities, there is a difference. Equity houses, as providers of what has become medium- to short-term investment funds, must make an effective exit and return debt to the institutions that finance their funds. The buoyancy of the market has enabled many funds to exit at a profit in less than five years; however, the degree of debt leverage (debt finance to earnings potential) could become problematic in a market downturn associated with higher interest rates or an external shock, for example, related to the cost of energy and energy supply. In addition to this, the media concentrates on the good news stories of rapid wealth creation in private equity; however, there are numerous unreported examples of private equity investments that fail. For example, private equity ownership and control failed to 
secure the future of Golden Wonder crisps, Little Chef road side restaurants and the Kwik Save supermarket chain.

\section{THE RESEARCH PROBLEMATIC: THEORETICAL AND EMPIRICAL LINKS BETWEEN PRIVATE EQUITY AND HRM}

A substantial US and British literature investigating the economic effects of private equity management buyouts demonstrates a positive, if not econometrically based association between renewed and restructured corporate organisation and the productivity and profitability of an acquired firm (see, for example, Jensen and Murphy, 1990; Rappaport, [1986] 1998; Bacon et al., 2004; Harris et al., 2005; Kaplan and Schoar, 2005). Theoretically, two sets of arguments explain improved performance at company level; on the one hand, operational improvements - what the HR community term performance management - may flow from a reduction in managerial discretion and an associated realignment of investor and owner interests with those of management (Achain and Demsetz, 1972; Jensen and Meckling, 1976; Jensen, 1986, 1989; Jensen and Murphy, 1990). Associated strategies for tighter managerial monitoring and incentivised performance are likely to centre on measures such as free cash flow, share price growth and monthly 'numbers'. Therein, active monitoring by investors and self-monitoring by managers lead to lower agency costs (in management discretion and opportunism) and lower transaction costs. Theoretically, this is the case as managers 'trickle down' performance management mechanisms to employee grades in the form of simple, technical and bureaucratic controls administered by the HR function. However, in the financial economics literature cited there is no discussion of the detail of these HR policies and strategies. On the other hand, performance improvements could result from a more overtly aggressive management of HR focused on the application of lower road approaches that reduce working capital and 'sweat' capital and labour by reigning in workplace pluralism. This has the effect of redistributing rents away from employee and customer stakeholders, moving to a more unitarist framework for workplace employee relations. See, for example, fervent criticism from the GMB union of the lower road strategies associated with private equity ownership at the AA, Bird's Eye and Gate Gourmet.

Turning to the empirical and institutional links between private equity and HRM, the latest edition of a prominent text that provides authoritative analysis of contemporary developments in the field includes a section on corporate governance (Bach, 2005: 24-26). While this is a welcome inclusion, much of the discussion emphasises the impact of managing for shareholder value on finance and ownership strategies in established features of short-termism in the British business system such as financial engineering and growth strategies centred around merger and acquisition activity. More quizzical contributions that emphasise stakeholder approaches to political economy and business organization seek to illustrate how American and British patterns of governance and ownership affect HRM. These approaches develop business system or firm-level frameworks to demonstrate the presence or absence of institutional complementarities that affect employers in different types of business system; for example, those that influence the extent to which employers can commit to 'higher road' HR strategies associated with 
high-performance work systems and resource-based approaches to the firm (Porter, 1998; Hall and Soskice, 2001: 1-70; Gospel and Pendelton, 2005; Clark, 2006). The theoretical and empirical issues that these arguments generate raise two research questions.

\section{HOW DOES THE BOUNDARY OF OWNERSHIP AND CONTROL INFLUENCE HR STRATEGY?}

Structurally, emphasis on the management of employment by a single employer exercising executive control over HR is now open to question. 'Permeable' - multiple interest-multi-owner controlled - organisations expose employment and HR issues to the sensitivities of co-owners and outside investors. Private equity controls 20 per cent of the UK's private sector (a controlling stake larger than the public sector) but holds controlling equity interests in many more public firms and supplies finance for private firms, often as a precursor to an initial public offering of shares. The research question that flows from these developments centres on how the presence of value-based, more financialised 'new HR' influences on HR managers unfold; for example, higher road approaches may appear inappropriate and unnecessary if employers or other controlling interests are unable or unwilling to maintain their commitment to customers, employees or established investors. Relatedly, questions of ownership and nationality effects and executive control must be addressed; for example, do private equity firms appoint senior management? Further, can operational managers exercise strategic choice and resist lower road approaches to HRM that some stakeholders may deem inappropriate to the long-term value of a firm? The boundary question over ownership and control suggests the potential for conflict between and within management as various stakeholders (private equity nominees, management controllers, rebel or activist investors) seek to influence HR strategies.

\section{AGENCY AND THE INEVITABILITY OF 'LOWER ROAD' HRM?}

Anecdotally, PEFs are associated with agency approaches to management that rationalise managerial discretion as beyond the interests of shareholders. In turn, this approach suggests that managers must be incentivised by contract to pursue shareholder interests through systems of target setting, performance management and monitoring. Agency and monitoring analyses of management behaviour, although theoretically robust, often oversimplify complex relations between management and outside investors and ignore the possibility of strategic choice by managers. Rather than automatically adopting lower road approaches to HRM, PEFs may deploy higher road approaches to HRM. Operationally and in theory, to secure shareholder value it is, in some sectors, unwise to hollow out existing HR strategies if the medium-term effect of this is a loss of managerial legitimacy and a decline in customer confidence and loyalty. For example, in the mid-1990s, some rail companies downsized driver numbers to such an extent that they were unable to deliver rail services in published timetables. Similarly, the GMB union claims that private equity ownership of the AA saw roadside staff downsized to such an extent that AA members had to wait much longer for roadside assistance and recovery, leading to 
a significant fall in membership renewals. A key empirical question is, what scope do managers have to enact strategic choice in HRM strategies under a shareholder value regime? The objective of evaluating private equity interventions in this way is to produce a measured appreciation of private equity, shareholder value and the market for corporate control rather than accepting and assuming that agency approaches always result in 'lower road' HR strategies. The significance of this approach is that it appears unwise to assume (as many advocates and critics do) that many of the business and HR strategies associated with private equity are wholly absent in the British business system beyond the private equity sector.

\section{FURTHER RESEARCH AND POLICY QUESTIONS FOR SCHOLARS AND PRACTITIONERS: RISK, DISTRIBUTION AND TRANSPARENCY}

The FSA discussion paper on private equity asks seven policy-related questions of which at least two deserve a significant consideration of HR issues (FSA, 2006, Annex 2). Questions 1 and 3 relate to issues of risk associated with private equity deals focusing on issues of excessive risk, unclear ownership of economic risk and market abuse. Each of these has a clear risk potential for HRM in a firm acquired by or controlled by private equity. Question 6 also relates to risk but places an emphasis on issues of inclusion in its fact finding. While significant, issues relating to distribution and transparency in the management of the employment relationship are conspicuously absent.

In stable economic conditions, voluntary controls that emphasise best practice may appear to benefit all. However, the issues of transparency, ownership and responsibility to employees and creditors have the potential to be even more complicated where efforts to maintain operational cash flow and profitability are secured by refinancing in the secondary private equity market. In turn, this issue is further complicated by a decision of the European Court for Justice in 2002 that allows the cross-border use of legal forms for business throughout the EU, that is, a nominally German firm operating in Germany could actually be registered as a UK plc with only a postal or electronic address in the UK. The evidence suggests that 13 per cent of new business registrations in Germany are not German $\mathrm{GmbH}$ registrations but British plc registrations. The HR issues that follow from this are best explained by a hypothetical example: assume that a UK plc operating mainly in the UK is bought out by a private equity take-private deal. The equity house, after a period of consolidation, makes an initial public offering of shares on a foreign but EU member stock market, breaking up its ownership of the previously UK company via the secondary private equity market; what is the country of origin? Current debates on private equity highlight this issue, but it does affect any firm that 'offshores' employment or its ownership. What happens to employee and HR interests and issues if via the secondary market the majority shareholder is American and seeks to buy out existing shareholders and reregister the company as a US- or Caribbean-based company? Employee interests should be secured by due process and country of operation labour law (at least in the EU), but transparency in decision making and employee involvement and participation in such issues are poorly developed at this stage. Even in multinationals, these issues are likely to be ultra vires to European Works Councils. The key point is, the scenario previously described 
may have only a marginal or negligible direct effect on HR issues, but because such moves lack transparency, it is difficult to identify or influence outcomes.

In conclusion, managing for shareholder value places financial engineering and the potential dangers that flow from it centre stage in corporate strategy. Private equity brings with it a clear value-creation strategy that incentivises senior managers in an acquired firm to act like owners, not managers. The unanswered and more significantly unasked questions on this relate to the contribution of private equity to the widening income disparity between executive remuneration and the pay of workers, particularly if financial performance demonstrates a growing business and higher productivity. Relatedly, to secure the leverage necessary to support an acquisition there may be downward pressures on pay, pension provision, job security and redundancy provision. In many cases, the effectiveness of management performance remains opaque, and the effectiveness of 'aligned' remuneration for both management and workers remains largely untested in the UK.

\section{REFERENCES}

Achain, A. and Demsetz, H. (1972). 'Production, information costs and economic organization'. American Economic Review, 62: 777-795.

Almond, P. and Ferner, A. (eds) (2006). American Multinationals in Europe: Human Resource Policies and Practices, Oxford: Oxford University Press.

Bach, S. (2005). 'Personnel in transition', in S. Bach (ed.), Managing Human Resources Personnel Management in Transition, Oxford: Blackwell.

Bacon, N., Wright, M. and Demina, N. (2004). 'Management buyouts and human resource management'. British Journal of Industrial Relations, 42: 2, 325-347.

Boxall, P. and Purcell, J. (2003). Strategy and Human Resource Management, London: Palgrave Macmillan.

British Venture Capital Association (BVCA) (2006a). BVCA Chairman's Speech, All Party Group for Venture Capital and Private Equity. Full Text Press Release, Monday 27 November. Available at http:/ /www.bvca.co.uk.

British Venture Capital Association (BVCA) (2006b). The Economic Impact of Private Equity in the UK, 2006. BVCA, December. Available at http:/ /www.bvca.co.uk.

Clark, I. (2006). 'Another third way?: VW and trails of stakeholder capitalism'. Industrial Relations Journal, 37: 6, 593-607.

Clark, I. and Almond, P. (2004). 'Dynamism and embeddedness: towards a lower road?: British subsidiaries of American multinationals and the British business system'. Industrial Relations Journal, 35: 5, 536-556.

Clark, I., Colling, T., Almond, P., Peters, R., Gunnigle, P., Morley, M. and Portillo, M. (2002). 'Multinationals in Europe 2001-2002: home country, host country and sector effects in the context of crisis'. Industrial Relations Journal, 33: 5, 445-463.

Colling, T. and Clark, I. (2002). " "Looking for Americanness": sector effects in engineering process plant contracting'. European Journal of Industrial Relations, 8: 3, 301-325.

Colling, T. and Clark, I. (2006). 'What happened when the Americans took over Britain's electricity industry? Exploring trans-national sector effects on employment relations'. International Journal of Human Resource Management, 17: 9, 1625-1644.

Financial Services Authority (FSA) (2006). Private Equity: A Discussion of Risk and Regulatory Engagement. Discussion Paper, 06/6, November, London: FSA.

Folkman, P., Froud, J., Sukhdev, J. and Williams, K. (2006). Working for Themselves? Capital Market Intermediaries and Present Day Capitalism. Centre for Research on Socio-Cultural 
Change, University of Manchester, working papers series no. 25. Available at http:// www.cresc.ac.uk.

Froud, J. and Williams, K. (2007). Private Equity and the Culture of Value Extraction. Centre for Research on Socio-Cultural Change, University of Manchester, working papers series no. 31. Available at http://www.cresc.ac.uk.

Gospel, H. and Pendelton, A. (eds) (2005). Corporate Governance and Labour Managementan International Comparison, London: Oxford University Press.

Hall, P. and Soskice, D. (2001). 'An introduction to the varieties of capitalism', in P. Hall and D. Soskice (ed.), Varieties of Capitalism: The Institutional Foundations of Comparative Advantage, Oxford: Oxford University Press.

Harris, R., Siegel, D. and Wright, M. (2005). 'Assessing the impact of management buyouts on economic efficiency: plant level evidence from the UK'. Review of Economics and Statistics, 87: 1, 148-154.

Jackson, T. (2006). 'Shades of old conglomerates in private equity trend'. Financial Times, 31 October, 13.

Jensen, M. (1986). 'Agency costs of free cash flow, corporate finance and takeovers'. American Economic Review, 76: 323-329.

Jensen, M. (1989). 'The eclipse of the public corporation'. Harvard Business Review, September, 62-74.

Jensen, M. and Meckling, W. (1976). 'Theory of the firm: managerial behaviour, agency costs and ownership structure'. Journal of Financial Economics, 3: 305-60.

Jensen, M. and Murphy, K. (1990). 'Performance pay and top-management incentives'. The Journal of Political Economy, 98: 2, 225-264.

Kaplan, S. and Schoar, A. (2005). 'Private equity performance returns, persistence and capital flows'. Journal of Finance, 60: 4, 1791-1824.

KPMG (2006). UK Buyout Deals See Most Valuable Quarter on Record. July. http://www. kpmg.co.uk/news.

Porter, M. (1998). The Competitive Advantage of Nations, 2nd edn, London: Macmillan Business.

Rappaport, A. ([1986] 1998). Creating Shareholder Value: A Guide to Managers and Investors, New York: The Free Press. 